\title{
Troska o podniesienie poziomu pracy wychowawczej w placówkach opiekuńczych na łamach czasopisma „Dom Dziecka” w latach 1954-1961
}

W wyniku wojny sprawa zasięgu sieroctwa i wyrównywania jego skutków urosła do rozmiarów jednego z najważniejszych zagadnień społecznych. Tysiącom osieroconych dzieci należało zapewnić opiekę. Podstawę prawną do jej sprawowania stanowiła jeszcze przedwojenna ustawa o opiece społecznej z dnia 16 sierpnia 1923 r. oraz nowy akt w postaci uchwały Rady Ministrów z 12 czerwca 1945 r. o podziale kompetencji opiekuńczych pomiędzy resorty zdrowia, oświaty oraz pracy i opieki społecznej. Na ich podstawie szereg instytucji prywatnych, społecznych, kościół oraz państwo wspólnie pełniły funkcję organizatorów różnorodnych form opieki całkowitej i częściowej osieroconymi dziećmi, rozwiązując ich bieżące problemy.

20 marca 1950 r. weszła w życie ustawa o terenowych organach jednolitej władzy państwowej, która wprowadziła centralny system zarządzania w państwie, także w sferze oświatowo-wychowawczej, zaś w uchwalonej przez sejm ustawie o planie 6-letnim wyznaczone zostały szczegółowe postulaty dla opieki nad dzieckiem. Były to m.in. ${ }^{1}$ :

- poprawa bytu dzieci osieroconych;

- zwiększenie liczby państwowych domów dziecka, gdyż tylko państwo ma najwłaściwsze ku temu warunki materialne i wychowawcze;

* Dr, Katedra Historii Wychowania i Pedeutologii, Wydział Nauk o Wychowaniu, Uniwersytet Łódzki, 91-408 Łódź, ul. Pomorska 46/48.

1 Zadania planu sześcioletniego w zakresie opieki nad dzieckiem, „Dzieci i Wychowawca” 1950, nr 3, s. 9-15. 
- dokonanie zmian w rozmieszczeniu placówek na terenie kraju w celu zapewnienia dzieciom i młodzieży kontaktu z zakładami pracy;

- umieszczenie dzieci w rodzinach zastępczych zdrowych klasowo, tj. drobnochłopskich, robotniczych;

- rozbudowa placówek opiekuńczo-wychowawczych opieki częściowej, w związku z aktywizacją kobiet w życiu gospodarczym.

Ustawa o terenowych organach jednolitej władzy państwowej z 20 marca 1950 r. zniosła samorządy terytorialne i przekazała państwu wypełniane przez nie zadania opiekuńcze. Rozwiązano więc organizacje społeczne, działające dotąd na rzecz sierot, m.in. Towarzystwo Burs i Stypendiów czy Towarzystwo Gniazd Sierocych i Wiosek Kościuszkowskich. W roku 1952 przestał działać także Polski Instytut Służby Społecznej, bardzo ważny ośrodek badawczy, zajmujący się pedagogiką opiekuńczą.

W celu łączenia programowych i finansowych podstaw opieki upaństwowiono wszystkie domy dziecka. Państwo przejęło całość majątku placówek prowadzonych dotąd przez inne instytucje, uznając, iż tylko ono może stworzyć najwłaściwsze warunki materialne (budynki i urządzenia techniczne) oraz wychowawcze (dobór personelu) dzieciom pozbawionym opieki rodzicielskiej.

W takiej oto rzeczywistości środowisko społeczników, pedagogów teoretyków oraz wychowawców pracujących w już upaństwowionych zakładach opieki nad dzieckiem, ale pamiętających jeszcze „dobre międzywojenne praktyki”, zaczęło domagać się specjalistycznej trybuny umożliwiającej wymianę myśli i poglądów związanych z szeroką problematyką opieki nad sierotami w nowych warunkach.

Pismem, które mogło spełnić oczekiwania środowiska w tym zakresie był właśnie „Dom Dziecka” - periodyk ukazujący się w czasach PRL, którego wydawcą było Ministerstwo Oświaty i Wychowania (MOiW). Jego zawartość miała w pierwotnych założeniach nawiązywać do najlepszych tradycji opiekuńczych okresu międzywojnia poprzez wzorowanie się na formule swego protoplasty - pisma „Opieka nad Dzieckiem” (1923-1932), które w najszerszy w tamtym czasie sposób podejmowało na swych łamach zagadnienia opieki nad sierotami w aspekcie higienicznym, organizacyjnym i wychowawczym.

Czasopismo „Dom Dziecka” powstało z inicjatywy dyrektora Departamentu Opieki nad Dzieckiem w MOiW Franciszka Pawuły i naczelnika Wydziału Domów Dziecka w tym ministerstwie - Marii Kondratowicz, jako efekt zapotrzebowania na wiedzę pedagogiczną, której brak sygnalizowało środowisko pracowników zatrudnionych w zakładach opieki nad dzieckiem. 23 kwietnia 1954 r. ukazał się pierwszy numer tego kwartalnika, adresowany przede wszystkim do wychowawców domów dziecka. Pismo redagował zespół w następującym składzie osobowym: Franciszek Pawuła - ówczesny dyrektor Departamentu Opieki nad Dzieckiem, Maria Kondratowicz - naczelnik Wydziału Domu Dziecka i Kazimierz Czajkowski - kierownik sekcji w Centralnym Ośrodku Doskonalenia Kadr Oświatowych (CODKO).

Od roku 1955 prowadzenie czasopisma przejął dr Maksymilian Maciaszek, pracownik naukowy w Instytucie Pedagogiki. Sekretarzem redakcji został wtedy Albin Kelm, ówczesny wizytator opieki nad dzieckiem w Ministerstwie Oświaty, zaś sekretarzem technicznym - Jadwiga Matuszewska². Pismo rozszerzyło

2 J. Ma cias zkowa, W dziesięciolecie pracy pisma, „Problemy Opiekuńczo-Wychowawcze” 1964, nr 4, s. 8. 
wówczas grono adresatów o wychowawców szkolnych, pozaszkolnych, personel pedagogiczny, pracowników administracji szkolnej, kuratorów sądowych, opiekunów i działaczy społecznych, jednak przede wszystkim przeznaczone było dla grona wychowawców placówek opiekuńczych.

Państwo ludowe, które nadało sobie jedyne upoważnienie do odpowiedzialności za los sierot, realizowało zadania opiekuńcze w placówkach, odbierając tym samym możliwość kierowania oraz pracy w nich tzw. wrogom klasowym, to jest jednostkom niepoprawnym politycznie. Skuteczne wychowanie zakładowe miało więc na celu poprawić sytuację sierot i dzieci opuszczonych, ale przede wszystkim wychować je na przyszłych budowniczych socjalizmu. Cel ten, który wynikał z założeń planu 6-letniego w odniesieniu do opieki nad dzieckiem, można było realizować jedynie poprzez dobrą organizację pracy w zakładach.

Na łamach „Domu Dziecka” w czasie jego 7-letniej edycji wyłania się obraz obszarów, które - zdaniem przedstawicieli władzy ludowej - winny być realizowane w pracy placówek, jest też wyrazem troski redakcji o podniesienie poziomu pracy opiekuńczej.

\section{Planowanie pracy wychowawczej}

Wieloletnie zaniedbania w systemowej pracy wychowawczej, spowodowane czasem wojny i doraźną organizacją opieki tuż po niej, były niewątpliwie przyczyną szeroko zakrojonej akcji prowadzonej na łamach pisma, związanej z planowaniem pracy wychowawczej w placówkach opiekuńczych.

Przyjmując słuszne założenie, że wychowawcy nie mają w tej kwestii wystarczającej wiedzy, przekazywano wręcz instruktażowe informacje o etapach i przebiegu tworzenia takiego planu, a także zalecano niezbędne czynności związane $\mathrm{z}$ jego konstrukcją.

Przekazując czytelnikom wyczerpujący zasób wiedzy o istocie i konieczności planowania pracy, zwracano uwage przede wszystkim na sformułowanie celu, głównego kierunku oraz zakresu konkretnej cezury czasowej potrzebnej podczas planowania. Skuteczne planowanie powinno odnosić się do czasu co najmniej roku, winno więc być realizowane w postaci rocznych planów.

Roczne planowanie pracy wychowawczej w placówkach winno bowiem mieć na celu wyznaczenie kierunku pracy, ale jednocześnie zapewnienie jednolitości wpływów i koordynacji poczynań wychowawczych, niezbędnych do „usunięcia przypadkowości, zagubienia w szczegółach i stawiania dzieciom nie powiązanych ze sobą wymagań. $Z$ tych samych względów plan powinien mieć charakter kierunkowy. Oznacza to, że poszczególne zadania obrane na dany rok muszą się wiązać ze sobą i wspierać wzajemnie"3.

\footnotetext{
${ }^{3}$ W. D e w i t z o w a, O planowaniu pracy w domu dziecka, „Dom Dziecka” [dalej: DD] 1960, nr 3 ,
} s. 31. 
W artykułach zwracano uwagę na potrzebę przemyślenia sensu wychowawczego działania; znaczyło to, że prowadząc pracę wychowawczą, należy mieć zawsze na uwadze całość zadań i ich ostateczny, najogólniejszy cel. Podpowiadano, co robić, by planowana praca dała dobre wyniki, a oddziaływanie wychowawcze było skuteczne: „należy podzielić je na etapy i w poszczególnych etapach położyć nacisk na coraz to inne sprawy i zagadnienia wybrane z całości programu"4. Wskazywano, że w procesie planowania koncentrować się należy na tych zagadnieniach, które w danym okresie uznane zostaną za najważniejsze lub dla których realizacji zaistnieją sprzyjające warunki. Ustalenie wspólnego dla wszystkich wychowawców celu da możliwość wzajemnej wymiany doświadczeń i doskonalenia metod, uczyni też codzienną pracę ciekawszą i bardziej twórczą.

W poświęconych planowaniu publikacjach ${ }^{5}$ zwracano uwagę na to, by w planach wychowawczych każdej placówki opiekuńczo-wychowawczej znalazły odbicie także podstawowe zadania, wynikające z samego jej charakteru, jak: zaspokojenie podstawowych potrzeb dzieci, kształtowanie nawyków codziennej kultury i praktycznych umiejętności pracy, przygotowanie do samodzielnego życia itp. Najważniejszym warunkiem prawidłowego planowania winna być dobra znajomość sytuacji, potrzeb i możliwości danej placówki. Planowanie powinno być świadome i zamierzone. Planując pracę należy jasno zdawać sobie sprawę, dlaczego te, a nie inne zadania wysuwają się na pierwszy plan i w jakim pozostają związku z tym, co już osiągnięto i co można osiągnąć w dalszej perspektywie. W wyniku takiej analizy plan pracy staje się konkretny i rzeczowy.

Oto porada, jak ten efekt osiągnąć:

Jeżeli na przykład chcemy obrać kierunek związany z rozwijaniem aktywności i samodzielności dzieci, sprzyjać temu może równocześnie zaangażowanie grupy czy zespołu do współudziału w rozwiązywaniu codziennych spraw domu.

Obrane zadanie znajdzie również odbicie w różnych dziedzinach pracy z dziećmi:

- w ustalaniu porządku dnia,

- w sposobie kierowania nauką własną wychowanków,

- w charakterze zajęć w wolnym czasie,

- w środkach normujących postępowanie, słowem w całym systemie oddziaływania wychowawczego ${ }^{6}$.

O realności planu, obok zadań, decyduje także dobór środków. Autorzy podejmujący problematykę planowania zauważają, że ta podstawowa zasada planowania wychowawczego: każdemu zadaniu towarzyszyć muszą odpowiednio dobrane środki, bywa często naruszana w praktyce, bowiem formułując zadania wychowawcy nie wskazują na sposób ich realizacji?:

${ }^{4}$ S. Papuziń s ki, Praca domu dziecka, DD 1958, nr 2, s. 16.

5 W. De wi tz o wa, O planowaniu...; S. P a p u z iń s ki, Praca...; A. Ka m iń s k i, Dom dziecka jako rozszerzona rodzina, DD 1959, nr 3.

${ }^{6}$ I. M i e ṙ̇a n, O pracy z dziećmi przedszkolnymi w domach dziecka, DD 1957, nr 5, s. 39.

${ }^{7}$ A. Ka mi ń s ki, Dom dziecka...; S. Pa puziń ski, Praca... 
Układanie planu rocznego da punkt wyjścia bardzo ważny, ale nie decydujący o rzeczywistej placówce w działaniu. Zapewnić je musi dobry tryb pracy, zabezpieczenie materialnych warunków dla projektowanych poczynań, zainteresowanie i pomoc ze strony kierownictwa w nadawaniu odpowiedniego kierunku wszystkim działającym na terenie domu ogniwom (komitet opiekuńczy, samorząd młodzieżowy, koło zainteresowań itd.). Wreszcie: bieżąca obserwacja przebiegu pracy, połączona z wymianą doświadczeń i z doskonaleniem na bieżąco metod oddziaływania ${ }^{8}$.

Ustalony w praktyce i najczęściej stosowany układ planu powinien służyć jako pomocnicze narzędzie w pracy zespołu wychowującego i codzienna pomoc w dobrej organizacji procesu wychowawczego w placówce.

\section{Praca jako główna metoda wychowawcza}

Drugą, obok planowania, istotną kwestią podejmowaną na łamach „Domu Dziecka" były refleksje teoretyków oraz praktyków wychowania na temat skuteczności stosowanych metod wychowawczych w pracy domów dziecka.

Placówki opiekuńcze to przecież miejsca przeznaczone dla specyficznej kategorii dzieci: opuszczonych, odrzuconych czy też w inny sposób pokrzywdzonych przez los. Dzieci te na skutek swoich przeżyć przejawiały specyficzne zachowania, które często uzewnętrzniały się m.in. lenistwem i niechęcią do pracy. Dlatego też, aby pomóc wychowawcom w przezwyciężaniu codziennych problemów z dziećmi, próbowano zwrócić ich uwagę na niedoceniane dotąd wychowawcze wartości pracy. Na łamach pisma popularyzowano więc jej walory. Wielokrotnie podkreślano potrzebę stosowania „specjalnych sposobów”, które pomogłyby wychowankom domów dziecka „wejść na dobrą drogę”. Jednym z tych sposobów była właśnie praca.

Zatem czas pobytu w domu dziecka, zdaniem redakcji, powinien być m.in. spożytkowany na nauczanie rzetelnej pracy, na wyrobienie przekonania, że praca w życiu człowieka jest niezbędna, że życie układa się pomyślniej tylko ludziom pracowitym. Ważne jest także, by wskazywać dzieciom sens jej wykonywania.

W każdej placówce powinien więc być sporządzony wykaz niezbędnych prac, od których wykonania zależy dobra organizacja życia domu. Powinna być też przyjęta zasada, że pracują wszyscy, każdy na miarę swoich możliwości, również pracownicy placówki. „Atmosferę pracy czy lenistwa w placówce tworzą pracownicy, dlatego też jest niezwykle ważne, aby jasno i wyraźnie określić obowiązki każdego pracownika i rzetelnie wykonać przez nich przyjęte zadania"”. Dzieci bowiem wzorują się na dorosłych, muszą więc mieć jak najlepszy przykład. Istotnie jest również równomiernie obciążenie dzieci pracą z uwzględnieniem ich możliwości oraz umiejętności. Piszący autorzy podkreślali mocno walor sprawiedliwej oceny. Wykonanie każdej pracy należy bowiem uczciwie ocenić, należy także

\footnotetext{
${ }^{8}$ W. Dewitzowa, O planowaniu..., s. 33.

${ }_{9}^{9}$ A. Ka mińs ki, Dom dziecka..., s. 12.
} 
wziąć pod uwagę stopień trudności i zaangażowanie dziecka w pracę. Najlepiej ocenić pracę może jednak ten wychowawca, który „wspólnie z dziećmi pracę wykonuje, śledzi jej przebieg, a także pokazuje, jak daną czynność najlepiej wykonać"10.

Wychowanie poprzez pracę powinno odbywać się nieustannie i regularnie w toku codziennych czynności. Prace wykonywane w domu dziecka przez dzieci należy podzielić na samoobsługowe, wykonywane codziennie w zamieszkiwanych pomieszczeniach i prace wykonywane dla domu w regularnych odstępach czasu. Ważne jest pamiętanie o proporcjonalnym włączaniu dzieci w codzienne prace domowe:

Wychowankowie domu od najmłodszych lat powinni być wciągani do pracy na rzecz ogółu, stosownie do ich wieku. Należy odnieść się do tego z analogią do podobnych świadczeń, jakie stosuje się dziś powszechnie w prawidłowo prowadzonym domu rodzicielskim. Dzieci pozostające $w$ domach po ukończeniu 14 lat, względnie szkoły podstawowej, powinny przyjmować na siebie bardziej odpowiedzialne obowiązki wobec młodszego dziecka lub wobec domu ${ }^{11}$.

Rady udzielane wychowawcom na łamach pisma odnosiły się także do zwrócenia ich uwagi na kwestię skutecznej organizacji pracy. Dobra organizacja eliminuje ociąganie się, dyscyplinuje i wskazuje sens podejmowanych przedsięwzięć. Wtedy w przyszłości wychowankowie w samodzielnym życiu będą cenić pracę i będą dobrymi pracownikami ${ }^{12}$.

Na łamach pisma podkreślano, że wychowawca, który pracuje w domu dziecka powinien uświadomić sobie nie tylko fakt, iż proces wychowawczy zaczyna się od lat najmłodszych - powinien pracować tak, by dziecko nie odczuło braku rodziców. Dom dziecka to nie tylko instytucja, gdzie dziecko rozwija się umysłowo i fizycznie, lecz także miejsce, gdzie powinno otrzymać miłość oraz zachwiane dotąd mocno poczucie bezpieczeństwa.

W artykułach, które podejmowały problem skutecznej pracy wychowawczej w domach dziecka pojawiała się często kwestia jej różnicowania w odniesieniu do poszczególnych grup wiekowych oraz związanej z wiekiem specyfiki. Udzielano zatem szeregu rad dotyczących przestrzegania określonych zasad w pracy z dziećmi młodszymi. Na przykład grupa przedszkolna, jak żadna inna, musi mieć stałego, odpowiedzialnego za nią wychowawcę. Praktyka częstego zmieniania wychowawcy musi się spotkać z negatywną oceną, szczególnie w odniesieniu do dzieci najmłodszych. W pracy z dziećmi przedszkolnymi konieczny jest wyjątkowo bliski kontakt uczuciowy.

Starsze przedszkolaki powinny mieć prawo poruszania się po terenie i za pozwoleniem wychowawcy wychodzenia nawet poza teren. Starszaki powinny być uczone samodzielności w różny sposób, mogą np. być wysyłane przez dorosłych z różnymi poleceniami do kuchni, do piwnicy itp. Jednak wychowawca winien zawsze upewnić się wcześniej, że dziecku nic nie grozi i czuwać, żeby w porę wróciło do grupy. Wychowawca powinien organizować indywidualne kontakty dzieci z personelem kuchni, szwalni lub pralni. Dzieci mogłyby np. odwiedzać kuchnię

\footnotetext{
10 Tamże, s. 10.

11 J. Małe c k i, O pracy wychowanków Domu Dziecka, DD 1954, nr 4, s. 17.

12 Tamże, s. 18-19.
} 
w takich dniach i godzinach, kiedy im nie grozi nieszczęśliwy wypadek. Mogłyby to robić podczas przygotowywania suchego posiłku lub podwieczorku. Należy dokładnie przemyśleć i zaplanować, kiedy dzieci mogą odwiedzić pokoje gospodarcze domu dziecka ${ }^{13}$.

Ida Mierżan, wychowanka Janusza Korczaka, która pracowała wiele lat jako wychowawczyni w warszawskich i łódzkich placówkach opiekuńczych uważała, że aby dziecko czuło się jak w prawdziwym domu, wychowawca powinien organizować z dziećmi zbieranie szczawiu, grzybów czy innych produktów, o które poprosi dzieci kucharka. Dzieci starsze i wychowawcy innych grup powinni też wyrażać młodszym dzieciom uznanie dla ich starań. Taka praca bardzo wiąże dzieci z domem i podnosi ich samopoczucie ${ }^{14}$. Indywidualna, praktyczna, uczestnicząca obserwacja daje bowiem dziecku możliwość zdobycia samodzielności, a także sprawia mu dużo przyjemność. Obowiązkiem wychowawcy jest przygotowanie dziecka tak, by umiało sobie radzić, jak dziecko w jego wieku wychowujące się w domu.

\section{Wybór kierunku kształcenia zawodowego}

Przejawem troski o podniesienie poziomu pracy w placówkach był często podejmowany na łamach pisma problem kształcenia i przygotowania wychowanków do pełnienia przyszłych ról zawodowych.

Umiejętność pracy, znajomość zawodu, miłowanie kraju w jego przeszłości i przyszłości, przywiązanie, rzetelność do wychowawców, konkretna postawa wobec życia i rzeczy materialnych to zdolność, którą trzeba postulować jako konieczną dla młodych ludzi wchodzących w życie ${ }^{15}$.

Wychowawca powinien zadbać, aby każdy wychowanek otrzymał przygotowanie do zawodu. Przygotowanie to powinno odpowiadać zainteresowaniom, uzdolnieniom i pracowitości wychowanka, ale również nie powinno kolidować z potrzebami kraju. W zasadzie jako kluczowe przyjmuje się wykształcenie zawodowe, na poziomie podstawowym i średnim. Dla mniej zdolnych lub wykazujących dystans do nauki - na poziom niższy. Wyjątkowo, bardzo zdolnym, a zarazem pracowitym jednostkom należy umożliwiać studia wyższe.

Młodzież kończąca szkołę podstawową nie powinna być zaskakiwana koniecznością decydowania się w ostatniej chwili na wybór szkoły zawodowej. Dziecko ma prawo być niezdecydowane co do wyboru zawodu. Pogawędka na temat: „kim chcesz zostać w przyszłości” powinna być przeprowadzana w placówce, po ukończeniu przez dziecko co najmniej piątej klasy i powtarzana cyklicznie 1-2 razy rocznie. Zbliża to dzieci w sposób odpowiedzialny do przemyśleń związanych z zagadnieniem wyboru przyszłego zawodu i wielu z nich ułatwi decyzję, a kierow-

\footnotetext{
${ }^{13}$ I. Mi erża n, O pracy z dziećmi..., s. 30.

14 Tamże, s. 30-32.

15 S. Papuzińs ki, Praca..., s. 14.
} 
nictwu domów zmniejszy trudności. Dużą pomoc w podjęciu decyzji co do wyboru zawodu dają zajęcia proponowane w placówce: majsterkowanie i dowolne zajęcia warsztatowe oraz oczytanie dziecka ${ }^{16}$.

\section{Wprowadzenie wychowanków do kręgu kultury}

Jednym z niezwykle ważnych przejawów troski o podniesienie poziomu pracy wychowawczej w domach dziecka było zwrócenie uwagi pracującym w nich praktykantom na realizację ważnego celu wychowania, za jaki uznano w tym czasie wprowadzenie wychowanków do kręgu kultury.

Autorzy artykułów podkreślali, że wiele dzieci opuszczonych, wychowawczo zaniedbanych i osieroconych nie wyniosło ze swoich domów rodzinnych elementarnych nawyków kulturalnych, nie zostało też dotąd wprowadzonych w trwałe wartości kultury narodowej. Również domy dziecka w swej dotychczasowej pracy nie kompensowały wystarczająco tego istotnego braku w wychowaniu. Należy zatem uznać go za kluczowy i stworzyć dzieciom wszelkie warunki, by mogły się w nich kształtować i rozwijać szeroko rozumiane nawyki kulturalne.

Wydziały oświaty i kierownicy domów dziecka powinni wspólnym wysiłkiem zmierzać do uczynienia z domów dziecka czynnych ośrodków kulturotwórczych, przede wszystkim dla własnych wychowanków, z czasem dla środowiska zewnętrznego ${ }^{17}$.

Nawyki kulturalne należy rozpocząć od pracy nad sobą, poprzez codzienne dbanie o własną higienę i swój estetyczny wygląd, potem o wygląd najbliższego otoczenia, szafki, w której dziecko trzyma rzeczy, pościelonego starannie łóżka i porządku pod nim, ładu w sali, w której mieszka z innymi. Kultura ta przenosić się powinna na poszanowanie wspólnego dobra, wspólnych rzeczy, z których korzysta na co dzień: krzesła, stołu, ale też rzeczy osobistych, jak ubrania czy buty.

Wdrażanie do kulturalnych nawyków realizować się też powinno w dbaniu o wygląd otoczenia wokół domu: czystości alejek, trawników, całego podwórka. Należy zatem kłaść nacisk na kulturę ogólną wnętrza domu, na czystość dzieci i stały porządny ich wygląd, na estetykę otoczenia zewnętrznego oraz na mobilizowanie i uruchamianie środków, których zadaniem byłoby stałe podnoszenie standardu kultury ${ }^{18}$. Środki te są bardzo liczne, a do ważnych, mogących najsilniej i wszechstronnie oddziaływać, tworząc kulturę środowiskową domu dziecka, zaliczyć należy bibliotekę i czytelnię dla dzieci' ${ }^{19}$.

Organizacja czytelnictwa dziecięcego w domach dziecka, zdaniem wielu autorów, może stać się potężnym instrumentem wychowawczym, wybitnie podnoszącym kulturę ogólną i umysłową wychowanków oraz personelu placówek.

\footnotetext{
16 Tamże, s. 11-12.

17 M. J a k u b o w s k i, Dziecko w systemie pedagogicznym Janusza Korczaka, DD 1958, nr 2, s. 27.

18 Z. Si e radzki, „Nasz Dom” im. M. Falskiej, DD 1960, nr 6, s. 32.

19 S. Papuziński, Praca..., s. 16-17.
} 
„Ponieważ w domach dziecka typ nowoczesnego czytelnictwa nie jest dotąd znany, konieczne jest w pilnym trybie przeszkolenie w zakresie bibliotekarstwa dziecięcego, z każdego domu, przynajmniej jednej wychowawczyni lub jednego wychowawcy na odpowiednim kursie organizowanym przez Ministerstwo Kultury, Centralny Zarząd Bibliotek"20.

$\mathrm{Na}$ łamach pisma zwraca się uwagę na wielorakie walory wychowawcze odpowiednio dobranej literatury oraz na rolę książki jako niezawodnego instrumentu w rękach wychowawcy, z wielu względów efektywniejszego w działaniu i łatwiejszego w stosowaniu niż inne. O tym, jak wielkie znaczenie przypisywano książce, niech świadczą następujące słowa:

Książka dzięki swym wartościom poznawczym poszerza zasób umysłowy dziecka, dzięki swym walorom emocjonalnym odgrywa dużą rolę w procesie wychowania estetycznego, moralnego, patriotycznego i kształtowania uczuć, daje wzory postaw i zachowań, prowokuje do samoanalizy, rozbudza wrażliwość estetyczną i wyobraźnię. Dzieci ze środowiska rodzinnego wykazują większe zainteresowanie czytelnictwem niż wychowankowie domów dziecka. Jest więc tu wiele do zrobienia, gdy chodzi o pracę wychowawczą ${ }^{21}$.

Autorzy, którzy na łamach pisma podejmowali kwestię zainteresowań czytelniczych dzieci z placówek opiekuńczych, zwracali uwagę na preferencje tematyczne wybieranej przez nie literatury. Charakterystyczną cechą zainteresowań czytelniczych wychowanków domów dziecka jest duża popularność książek o „cieple domu rodzinnego". Wpływa na to fakt, że dom dziecka nie jest w stanie skutecznie zaspokoić potrzeb emocjonalnych dzieci, takich jak potrzeba serdeczności, zrozumienia, indywidualnego podejścia. Wychowankowie odczuwają wielką tęsknotę za domem. Dlatego omawiając rolę książki w procesie wychowawczym prowadzonym w domu dziecka, należy podkreślić, że w tym specyficznym środowisku nabiera ona jeszcze większego znaczenia. Kompensuje braki więzi uczuciowej, której potrzebę wychowankowie tak bardzo odczuwają. Czytelnictwo książek również wzbogaca słownictwo i wyrównuje wiele innych braków, np. losy bohaterów mogą być zachętą do pokonania trudności, które staną na ich własnej drodze ${ }^{22}$.

\section{Wolny czas dzieci}

Problemem, który w kontekście dyskusji nad skutecznością pracy wychowawczej w domach dziecka na łamach pisma zajął wiele miejsca, była kwestia zagospodarowania dzieciom z placówek opiekuńczych czasu wolnego.

Dziecko ma prawo do czasu wolnego, który częściowo powinno poświęcić na udział w organizowanych przez dom zajęciach dowolnych, w części zaś ma go do własnej dyspozycji. Zadaniem wychowawcy jest czuwanie nad równowagą

\footnotetext{
${ }^{20}$ W. D o m a g a t o w s k a, Czytelnictwo w Domach Dziecka, DD 1954, nr 3, s. 25.

${ }^{21}$ Z. Sieradzk i, „Nasz Dom”..., s. 30.

22 W. D o ma gat ow s ka, Czytelnictwo..., s. 23-25.
} 
spędzania czasu wolnego. Dzieci, które nadmierną część swojego czasu wolnego zużywają na bezmyślne bałaganienie, powinny być pod szczególną opieką wychowawcy, którego zadaniem jest aż do skutku próbować wciągnąć dziecko do kręgu pozytywnych zainteresowań. Większość wychowanków przybywa do placówki z małym doświadczeniem związanym z formami pozytywnego spędzania wolnego czasu, w wielu przypadkach są to doświadczenia ujemne.

W skutek zaniedbań wychowawczych w rodzinie u wielu dzieci występuje ubogie zaspakajanie potrzeb biologicznych, natomiast potrzeby społeczne są nie rozwinięte. Szczególnie słabo ożywione są potrzeby poznawcze i estetyczne, co zawęża wybór form i motywację aktywności wychowanka w czasie wolnym ${ }^{23}$.

Domy dziecka mają z reguły lepsze warunki materialne do organizowania czasu wolnego niż przeciętna rodzina wychowanka. Korzystniej niż w ich dotychczasowych rodzinach przedstawiają się możliwości wzbogacenia i wychowawczego ukierunkowania czasu wolnego. Przede wszystkim dom dziecka ma lepsze warunki rozwoju i zaspokojenia potrzeb społecznych.

W domu dziecka możliwe są do wykorzystania wszystkie znane sposoby spędzania wolnego czasu, od wypoczynku biernego, gier stolikowych, do możliwości korzystania z placów gier i zabaw, wyposażonych w bardziej skomplikowane urządzenia, od rysunku do zajęć plastycznych, od inscenizacji do teatru amatorskiego. Szczególne miejsce zajmują środki masowego przekazu, zwłaszcza radio ${ }^{24}$.

Nie można zapomnieć o czasie wolnym podczas wakacji. W większości domów sprawa wczasów letnich dla dzieci nie jest wcale rozwiązana. Dzieci nie wyjeżdżające do rodzin powinny znaleźć się na koloniach. Może się okazać, że korzystne jest organizowanie kolonii własnych, ewentualnie wspólnie z sąsiednimi domami dziecka. Okres wczasowy może i powinien być wykorzystany dla wzmocnienia pracy wychowawczej ${ }^{25}$.

Jedną z ważnych form aktywności - zauważali autorzy - na której należy bazować podczas organizacji dzieciom czasu wolnego, są zajęcia sportowe. Wyładowanie potrzeby ruchu fizycznego na powietrzu należy traktować na co dzień jako nieodzowny warunek normalnego, pełnego rozwoju dzieci i młodzieży. Stopniowe stwarzanie we wszystkich domach warunków odpowiadających współczesnym poglądom na tę dziedzinę życia dzieci powinno stać się szczególną troską wydziałów oświaty, kierownictwa domów, a także wychowawców. Należy dążyć do zakładanie boisk, placów zabaw i gier ruchowych, ślizgawek. Prawidłowemu wyżyciu się dzieci i młodzieży w ruchu fizycznym przypisuje się wybitne znaczenie wychowawczo-moralne ${ }^{26}$.

$\mathrm{Na}$ łamach pisma wskazywano na różny, często odmienny stosunek wychowawców domów dziecka do wychowania fizycznego i sportu. Są domy, w których

${ }^{23}$ K. Czajkowski, Czesław Babicki jako teoretyk wychowania zakładowego, DD 1957, nr 3, s. 22.

${ }^{24}$ A. Ke I m, Czas wolny wychowanków domów dziecka, DD 1956, nr 5, s. 17.

${ }^{25}$ S. Papuziński, Praca..., s. 18.

26 Tamże, s. 17. 
sport zajmuje ważne miejsce w pracy wychowawczej, ale są również takie, w których w ogóle się go nie docenia. Argumenty na rzecz uprawiania sportu w placówkach mogą być dwojakiego rodzaju. Pierwszy z nich może dowodzić konieczności wprowadzania sportu z punktu widzenia wymogów fizjologii rozwoju fizycznego dziecka, drugi - bezpośrednio wychowawczej wartości wychowania fizycznego i sportu, dużej użyteczności w pracy pedagogicznej w domu dziecka ${ }^{27}$.

O tym, na jakim poziomie i jak interesujące będą organizowane zajęcia z dziećmi podczas ich wolnego czasu decydują umiejętności zespołu wychowawców. Dlatego w rozważaniach dotyczących przygotowania wychowawców do pracy wysuwa się postulat opanowania przez każdego z nich określonej umiejętności praktycznej w zakresie organizacji czasu wolnego, a więc zajęć: sportowych, krajoznawstwa, artystycznych, turystyki, majsterkowania, gospodarstwa domowego i innych.

\section{Przygotowanie do samodzielności}

Przygotowanie do samodzielności jest podstawowym celem, ale też głównym zadaniem formułowanym w pracy wychowawczej domów dziecka. Kwestia ta znajdowała swoje odbicie także na łamach „Domu Dziecka”. Ponieważ pismo w swym założeniu miało być trybuną wymiany myśli i doświadczeń, również dla wychowawców praktyków, najpełniej realizuje się owo mocno demokratyczne założenie podczas wymiany doświadczeń na temat realizacji zadań związanych z procesem usamodzielnienia wychowanków.

Problem ten najczęściej poruszali wychowawcy praktycy z kilkunastoletnim stażem. Dzielili się doświadczeniem związanym z procesem przygotowywania swoich wychowanków do osiągnięcia przez nich samodzielności.

Wśród wielu trudnych zagadnień piętrzących się przy zakończeniu każdego roku szkolnego, najważniejsze miejsce zajmuje problem usamodzielniania młodzieży Zakończenie pierwszego i najważniejszego etapu kilkuletniej, ciężkiej pracy wychowawczej jest ewidentnie sprawą pierwszorzędnej wagi. Najważniejsze dlatego, że od tego, jak dom dziecka przygotuje młodzież, zależy ich przyszłe samodzielne życie ${ }^{28}$.

Piszący na ten temat autorzy zwracali uwagę na wysoki poziom lęku samych wychowanków, którzy za moment mają „samodzielnie pójść w świat”. W domu dziecka przecież każdy z nich zaspokaja wszystkie swoje potrzeby, nie myśląc o tym, skąd się biorą na to pieniądze i ile wysiłku trzeba włożyć, by stworzyć dzieciom najlepsze warunki zamieszkania.

Podkreślano także, iż sami wychowawcy podczas swojej codziennej pracy nie zdają sobie w pełni sprawy z wpływu, jaki mają na dobre przygotowanie młodego

${ }^{27}$ C. Prok o p c z y k, O roli sportu w domach dziecka, DD 1960, nr 6, s. 43.

${ }^{28}$ L. Kozdajewska, Jak pracujemy nad przygotowaniem wychowanek do samodzielnego życia, DD 1955, nr 3, s. 45. 
człowieka do samodzielności. Raczej na co dzień nie myślą o tym, że młodzież za moment opuści dom dziecka i będzie musiała troszczyć się sama o to, w co ma się ubrać, co zjeść, jak pracować, gdzie zamieszkać. I wtedy najmocniej widać codzienne efekty tej pracy i ewentualne główne przyczyny niezaradność wychowanków.

Drugą niezwykle ważną sprawą jest przygotowanie wychowanków do pracy. Poważną kwestię w tym zakresie stanowi zapewnienie im pozyskania właściwego zawodu. Danie wychowankowi niedostatecznych kwalifikacji zawodowych czy dopuszczenie do nieodpowiedniego wyboru zawodu pociąga za sobą przykre następstwa. Niewłaściwie przygotowany do pracy wychowanek albo przez całe życie będzie złym pracownikiem, albo też porzuci pracę i zajmie się stosowniejszym dla siebie zajęciem. Takich wypadków jest w domach dziecka dużo. Przygotowanie wychowanka do usamodzielnienia należy rozpocząć od pierwszego dnia jego pobytu w domu dziecka.

Czy dziecko będzie skierowane do odpowiedniej szkoły i czy w tej szkole znajdzie właściwe miejsce, zależy od kierowników i wychowawców. Wychowankowie dobrze przygotowani do życia nie boją się go, odważnie wstępują na nową drogę samodzielności. Dzieci kończące technika nie sprawiają większych problemów przy usamodzielnianiu. Pomaga tutaj danie absolwentom technikum nakazów pracy, skierowań, które stanowią podstawę do pozyskania mieszkania, a tym samym rozwiązują najpoważniejsze problemy w pierwszych dniach po ich usamodzielnieniu ${ }^{29}$.

Więcej natomiast kłopotów sprawiają wychowankowie po ukończeniu różnego rodzaju kursów. Niedługo trwający kurs rzadko daje dobre przygotowanie i gwarancję samodzielnego radzenia sobie w skomplikowanych sprawach zawodowych. Znalezienie pracy dla dzieci kończących takie kursy sprawia spore trudności kierownictwu placówek. Są także dzieci, które kończą szkołę zasadniczą w wieku 16 lat, co stanowi formalną przeszkodę w znalezieniu pracy dla tak młodego wychowanka.

W toku procesu usamodzielnienia, już w ciągu roku szkolnego wychowawcy starają się, by każdy wychowanek kończący szkołę dostał przydział pracy i mieszkanie. Troszczy się o to nie tylko kierownik domu, lecz także cały personel. To w dużej mierze likwiduje trudności związane z usamodzielnianiem i utwierdza wychowanków w przekonaniu, że jest ktoś, kto martwi się o to, żeby w życiu było im dobrze. „Niestety, w tych sprawach miejscowe władze rzadko przybywają z pomocą, pozostawiając kłopoty wyłącznie kierownictwu domu. Zważywszy na to przedłuża się często pobyt wychowanka usamodzielnionego w domu dziecka. Uprzednio również personel domu myśli o przygotowaniu wyprawek dla usamodzielniających się wychowanków"30.

Wychowawcy starają się, aby sam moment odejścia dziecka z domu wypadł bardzo uroczyście i w jak najlepszym nastroju. Wychowankowie, którzy zostają

${ }^{29}$ M. J a k u b o w s ki, Problem aktywności w zakładach Janusza Korczaka, DD 1958, nr 2, s. 35.

${ }^{30}$ K. M azu re k-Kow al s k a, Odejście wychowanka z Domu Dziecka, DD 1955, nr 3, s. 28. 
w domu dziecka, wyjątkowo serdecznie żegnają odchodzące koleżanki czy kolegów. Takie chwile przeżywają wszyscy bardzo mocno. Nie pamięta się wtedy o tym, że ten lub inny wychowanek sprawiał często wiele kłopotu. W dniu usamodzielniania tacy wychowankowie są dla wychowawców dumą i radością. Wychowawcy dbają również o to, żeby serdeczny i miły stosunek do domu dziecka nie zmienił się w chwili opuszczenia jego murów. Domy dziecka starają się utrzymać kontakt ze wszystkimi usamodzielnionymi wychowankami. Bardzo często wychowankowie przy różnych okazjach odwiedzają dom i opowiadają o swoim nowym, samodzielnym życiu. Problemy związane z usamodzielnianiem wychowanków są często tematem obrad Rady Pedagogicznej Domu. Zalicza się je do najważniejszych w pracy pedagogicznej placówek.

Na łamach „Domu Dziecka” doświadczeniami z procesu przygotowania swoich wychowanków do samodzielnego życia dzielili się wychowawcy placówek o różnym charakterze. Lucyna Kozdajewska przez wiele lat pracowała w domu dziecka dla dziewcząt. W jednym z artykułów przesłanych do redakcji dzieliła się swoimi doświadczeniami, jak skutecznie przygotować dziewczęta z domu dziecka do wejścia w samodzielność.

Przygotowanie wychowanek do samodzielnego życia odbywa się wielostronnie. Dziewczynki uzyskują wiele umiejętności, które są potrzebne każdej kobiecie w jej samodzielnym życiu. Staranie o te codzienne, ale bardzo ważne sprawy znajduje właściwe sformułowanie w planach rocznych, miesięcznych i tygodniowych ${ }^{31}$.

L. Kozdajewska uważa, że w planie powinny być zawarte środki do realizacji procesu usamodzielnienia. Są to m.in.:

a) codzienne dyżury przy myciu naczyń, sprzątaniu i robieniu kolacji;

b) pomoc dziewczyn przy przygotowywaniu zapasów na zimę;

c) organizowanie „dni samodzielności”;

d) nauka cerowania i szycia;

e) wyrobienie u wychowanek poszanowania bielizny, pościeli i ubrań32.

W pracy wychowawczej opisywanej placówki duży nacisk kładzie się na aktywizację samorządu młodzieżowego, praca w samorządzie bowiem jest szkołą życia dla wychowanek. Przez pracę w sekcji gospodarczej i porządkowej dziewczyny zapoznają się z prowadzeniem gospodarstwa domowego. Jednak z uaktywnianiem dziewczynek, zainteresowaniem ich pracą są spore trudności. Można zauważyć, że młodsze dzieci z większym zaangażowaniem podejmują wszelkie prace, z kolei dorastające dziewczyny często mają niewłaściwy stosunek do pracy fizycznej.

L. Kozdajewska zauważa także wartości, jakie mają spotkania wychowanek z już usamodzielnionymi koleżankami. W ciągu całego roku szkolnego wiele wysiłku wychowawczynie wkładają w to, żeby przekonać nowo przyjęte do placówki dziewczęta do korzyści, które w przyszłości wyniosą z pracy na terenie domu dziecka. Odbywa się to często właśnie poprzez spotkania z usamodzielnionymi

${ }^{31}$ L Kozdajew ska, Jak pracujemy..., s. 45.

32 Tamże, s. 47. 
już wychowankami. W czasie takich kontaktów wychowawcy starają się tak pokierować rozmową, by starsze, usamodzielnione wychowanki potwierdziły pożytek, jaki dało im zgłaszanie się do prac domowych. Przykłady z ich życia są bardziej przekonujące niż słowa. Dziewczynki biorą udział we wszystkich pracach na terenie domu i są zorientowane $w$ gospodarowaniu zakładu. Obeznane są z budżetem, znają ceny za wyżywienie, odzież, pomoc naukową itd. W małych grupkach dziewczynki obliczają wartość pieniężną dziennego wyżywienia, zaznajamiają się z cenami poszczególnych produktów. W ramach prac sekcji gospodarczej wychowanki układają jadłospis $z$ jednoczesną kalkulacją pieniężną. Jadłospisy sporządza przewodnicząca sekcji z coraz to inną grupą wychowanek, żeby miały możliwość zapoznania się ze sprawą żywienia ${ }^{33}$.

Dom dziecka stara się jak najlepiej wyposażyć usamodzielniające się wychowanki. Wyprawki szykuje się przez wiele lat. „Zwykle po 3, 4 latach pobytu w domu dziecka wychowanka wychodzi, mając: 3 pary butów, 2 płaszcze, 9 kompletów bielizny, ok. 10 sukienek, 2 spódniczki, fartuch ochronny do pracy i kilka bluzek, a także przybory toaletowe" 34 .

Każda wychowanka opuszczająca dom umie gotować, przygotowywać zapasy na zimę, a także prasować, prać i szyć odzież. Lekcji gotowania udzielają sobie nawzajem wychowanki. Fachowymi instruktorami są kucharki i intendentka. Samodzielne przygotowanie posiłków, kiedy dwie wychowanki gotują śniadanie i obiad dla 90 osób, a jedna kolację jest bardzo odpowiedzialną pracą. Wychowanki zdają sobie sprawę z tej odpowiedzialności. Celem dziewczyn jest dobre wywiązanie się z obowiązków, ponieważ całą ich pracę ocenia zespół, który spożywa zrobione przez nie potrawy. Dyżury przy gotowaniu, sprawowane w „Dniu samodzielności", są wykonane znacznie lepiej niż pozostałe. O tym, jak bardzo przydaje się umiejętność gotowania $w$ ich samodzielnym życiu, mówią same w czasie odwiedzin ${ }^{35}$.

Dużą uwagę w codziennej pracy wychowawczej domu skupia się na tym, aby wychowanki umiały uszyć sobie najprostsze rzeczy. Te wychowanki, które mają więcej czasu, uczą się zasad kroju i same próbują swych sił, szyjąc prostą odzież. Niektóre dziewczyny tak polubiły szycie, że pragną po skończeniu szkoły uczęszczać na kurs krawiecki, żeby udoskonalić swoje umiejętności. Od wszystkich wychowanek wymaga się, aby umiały cerować.

W codziennej pracy z wychowankami dużo uwagi poświęca się dbałości o urządzenia domu dziecka. W okresie gruntownego sprzątania wychowanki wraz z pracownikami domu odświeżają sprzęty domowe, przywracają im w miarę pierwotny wygląd, ale też naprawiają drobne uszkodzenia. W czasie letnim dziewczynki pracują również w ogródku, w którym sadzą warzywa i kwiaty. Ta praca również pomaga im $w$ ich samodzielnym życiu.

\footnotetext{
33 Tamże, s. 46.

34 Tamże, s. 48.

35 Tamże, s. 49.
} 


\section{Doskonalenie wychowawców}

Podniesienie poziomu pracy wychowawczej w placówkach opiekuńczych nie może odbywać się bez ustawicznego doskonalenia pracującej w nich kadry. Kwestia odpowiedniego przygotowania do pracy wychowawców pojawiała się często na łamach pisma.

W czasopiśmie wielokrotnie podkreślano, że do prawidłowej pracy w domach dziecka niezbędne jest rozszerzenie wiedzy wychowawców w zakresie ekonomii, polityki, socjologii i pedagogiki społecznej. Wychowawca powinien rozporządzać wiedzą i doświadczeniem, które umożliwi mu prawidłowe oddziaływanie na osobowość młodego wychowanka. By stać się wiarygodnym w swojej pracy, wychowawca powinien, oprócz wiedzy, korzystać ze sprawdzonych doświadczeń radzieckich towarzyszy. Wzorem wychowawcy, który może stać się najlepszym przykładem skutecznego rozwiązywania najtrudniejszych problemów wychowawczych z młodzieżą, jest wielki radziecki pedagog Antoni Makarenko ${ }^{36}$.

Szeroka wiedza i doświadczenie wychowawców, zdobyte w procesie intensywnej pracy nad sobą, ma im pomóc w podejmowaniu trafnych decyzji, ma zwiększyć stopień skuteczności i pewności w pracy wychowawczej. Rozszerzenie wiedzy wychowawców powinno objąć zagadnienia wybrane stosownie do potrzeb pracy wychowawczej, a także ułatwić możliwość poznawania środowiska społecznego poprzez umiejętność opracowania indywidualnego wywiadu społecznego dla celów opiekuńczo-wychowawczych ${ }^{37}$.

Wychowawcy każdego domu dziecka wspólnie, jako zespół, oprócz poprawnej politycznie sylwetki, powinni dysponować zasobem praktycznych umiejętności, niezbędnych do wzbogacenia procesu wychowania, do uczynienia wychowania atrakcyjnym, z pełnym przygotowaniem dzieci do życia.

Do umiejętności tych zaliczyć można m.in.:

1) znajomość zasad bibliotekarstwa dziecięcego, umiejętność prowadzenia biblioteki i czytelni dziecięcej;

2) umiejętność prowadzenie orkiestry na łatwych do opanowania przez dzieci instrumentach strunowych;

3) znajomość gier i zabaw dziecięcych pokojowych i na powietrzu, umiejętność zachęcenia do nich dzieci;

4) umiejętność prowadzenia sportów dziecięcych i wychowania fizycznego dzieci;

5) znajomość robót ręcznych i metod politechnizacji dzieci w ramach ich zajęć dobrowolnych, umiejętność prowadzenia majsterkowania;

6) umiejętność prowadzenia dobrowolnych zajęć przyrodniczych;

7) inne umiejętności nadające indywidualne cechy poszczególnym domom ${ }^{38}$.

Rola dobrej pracy wychowawczej polega na tym, aby w całym procesie wychowawczego dać dzieciom potrzebne umiejętności, przeżycia odpowiadające

${ }^{36}$ K. C z a j k o w s ki, Makarenko - praktyk i teoretyk wychowania, DD 1959, nr 7, s. 2.

${ }_{37} \mathrm{Z}$. Z a b o r o w s k i, Koncepcja wychowania w systemie pedagogicznym Antoniego Makarenki, tamże, nr 9, s. 7.

38 S. Papuzińs ki, Praca..., s. 14. 
wiekowi dziecka, a także na przyszłość dobre wspomnienia, które zazwyczaj decydują o psychicznej i moralnej postawie, o sile życiowej byłego wychowanka, o jego przydatności społecznej.

Kierownicy domów dziecka w ścisłym porozumieniu z wydziałami oświaty powinni poświęcić szczególnie wiele uwagi stwarzaniu warunków organizacyjnych i rzeczowych do efektywnego wychowania, co w efekcie pozwoli na osiągnięcie pełnych możliwości wyników bez nadmiernego nakładu sił i środków. Wychowują albowiem nie tylko wychowawcy, ale i zespół warunków, treści i tryb życia, nastrój, jaki obok ludzi stwarzają przedmioty, ich stan, urządzenia, porządek przedmiotowy ${ }^{39}$.

Analiza zawartości treści pisma w zakresie podjętej problematyki pozwala stwierdzić, że stanowiło ono znaczącą pomoc w zakresie wyznaczania kierunków pracy wychowawczej w placówkach opiekuńczych, a jako organ Ministerstwa Oświaty i Wychowania starało się, by zawarte w nim wskazówki utożsamić z politycznym kierunkiem $w$ opiece nad dzieckiem sierocym, wyznaczanym przez kolejne uchwały PZPR. Treści artykułów musiały być zatem zgodne z przyjętą polityczną doktryną, bowiem cenzura nie dopuszczała innych wrogich klasowo myśli.

W artykułach daje się wyraźnie zauważyć realizacja strategii oświatowej partii i rządu jako źródło upowszechniania jej zadań, zważywszy, że po 1956 r. prenumerata pisma stała się obowiązkowa dla wszystkich placówek opiekuńczych. Zdecydowanie przejawia się duch oddziaływania kolektywnego, którego celem było wychowanie sierot na przyszłych budowniczych socjalizmu.

W publikacjach można zauważyć realizację związku wychowania zakładowego z życiem klasy robotniczej poprzez dominację kształcenia zawodowego w placówkach. Wychowanie zespołowe dominuje nad indywidualną pracą z dzieckiem.

$\mathrm{Na}$ łamach pisma w badanym okresie nie podejmowano także kwestii związanych z rodzinnymi formami opieki ani problemów związanych z poprawą warunków pracy wychowawców, mocno wówczas obciążonych pracą, bez dodatkowej za nią gratyfikacji, choć wiele miejsca poświęcono potrzebie ich stałego kształcenia i doskonalenia.

Mimo to czasopismo „Dom Dziecka” dawało możliwość wypowiedzi ówczesnym teoretykom, praktykom wychowania oraz urzędnikom w kwestii wspomagania organizacji pracy wychowawczej w instytucjach opieki zamkniętej, było pomocne w kwestii wspierania idei centralnego zarządzania wychowaniem w placówkach, a zawarte w nim treści stanowiły przejaw troski państwa o skuteczną i sprawną pracę opiekuńczo-wychowawczą w organizowanych i prowadzonych instytucjach dla dzieci.

39 Tamże, s. 15. 